\title{
CONTEMPLAÇÃO DO PÔR DO SOL EM TEMPOS DA COVID-19 ${ }^{15}$
}

\section{DOI: http://dx.doi.org/10.18616/intcov64}

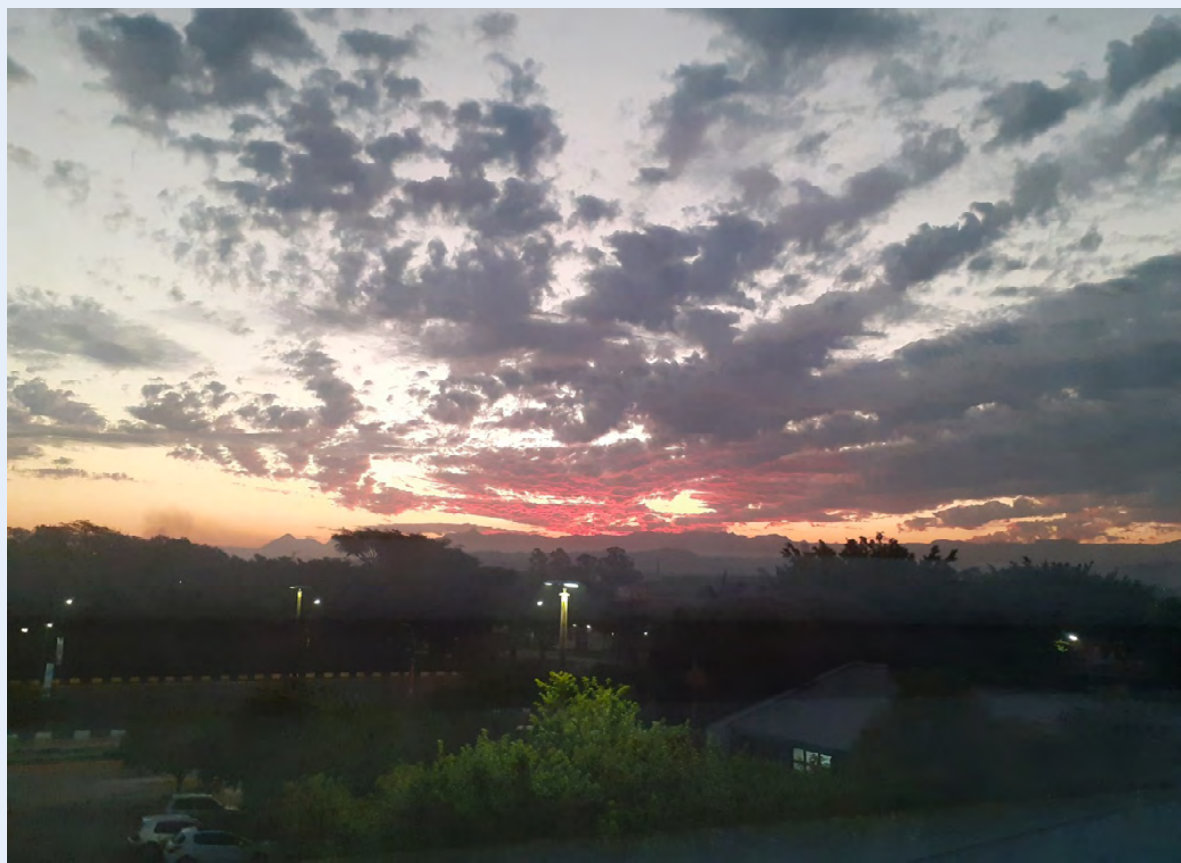

Créditos: Andréia Borges Bartolomeu.

A

O

15 Nos momentos normais, corrido do nosso dia a dia, talvez não contemplamos as belezas que a natureza nos proporciona, agora que estamos no meio de uma pandemia, que nos fez parar, diminuir nosso ritmo, tudo agradecemos e contemplamos, e que assim permaneça sempre. 